\title{
Roles and Effects of Human Network of Supporting Experts out of Niigata University to Practical Engineering Education
}

\author{
http://dx.doi.org/10.3991/ijep.v6i1.5360

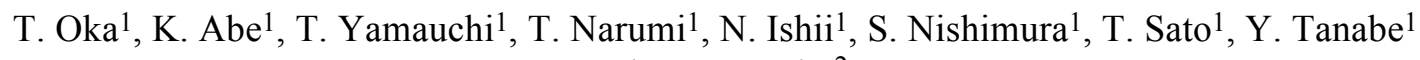 \\ and M. Sengoku ${ }^{2}$ \\ ${ }^{1}$ Niigata University, Niigata, Japan \\ ${ }^{2}$ Graduate Institute for Entrepreneurial Studies, Niigata, Japan
}

\begin{abstract}
The educational supporting human network outside the university we call as "The network of 100 wises" has been constructed by Faculty of Engineering in Niigata University on the process of educational reform activities. We have operated various kinds of practical programs on engineering education which have been assisted by the engineers/scientists in private companies and the societies outside the university. Since the network members possess the various experiences through the processes of their practical $R \& D$ activities, the guidance, lectures, and advice by the network members are much beneficial for the university students as well as for the faculties engaged in the engineering education. The network is composed of the engineers/scientists of various generations and industrial areas, mainly based on the personal reliances with the faculties through their research collaborations. It is much advantageous for the university students to obtain the practical engineering skills and the ways of thinking by means of the cooperation with the network.
\end{abstract}

Index Terms-educational reform, engineering education, research collaboration, supporting human network.

\section{INTRODUCTION}

The necessity of reforms in the higher education systems has been enthusiastically stated even in universities worldwide. As commented by Miller, it is needed to redefine the engineering education and to attract more students to the profession [1]. The need strongly related to the changes of the educational circumstances such as the elevation on amount of applicants of admission, the resultant decline of the scholastic ability of students, the internationalization of whole society, and so on. In these trends, Education Centre for Engineering and Technology (ECET) was established in Faculty of Engineering in Niigata University in 2004. ECET was at first composed of four branches and sustained by fourteen staffs which were assigned by four full-time and additional posts to develop and conduct the novel educational programs. The centre has also taken some important roles to organize and conduct various educational reform projects, which were adopted by the Japanese government [2].

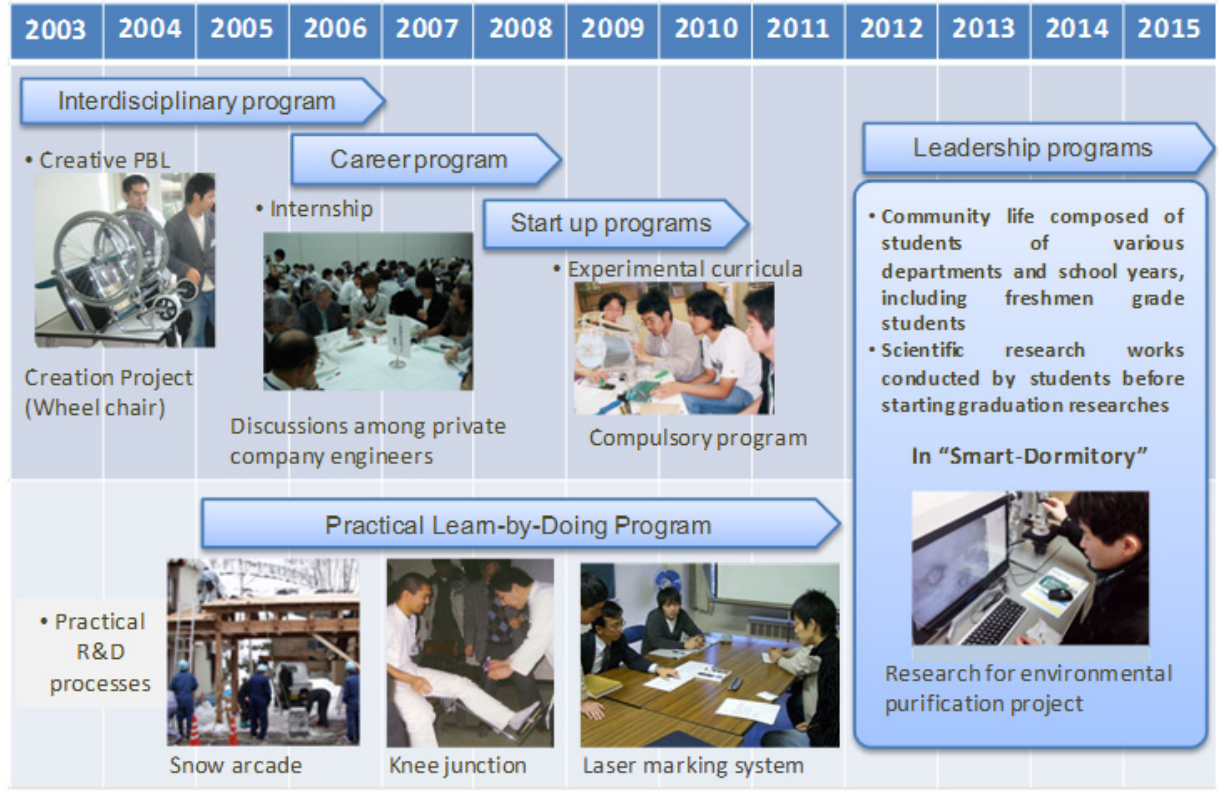

Figure 1. History of educational reform programs driven in Faculty of Engineering in Niigata University. 


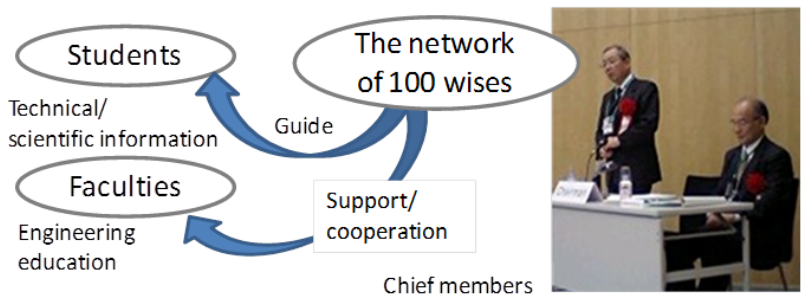

Figure 2. Roles of the educational human network "The network of 100 wises" and the chief members.

It is socially required for the faculty of universities conducting the engineering education courses to nurture the university graduates who would be capable of finding and resolving the practical issues by themselves in their job circumstances. In the process of educational reform activities, we have aimed to develop the novel educational programs which have been characterized by the practical education, such as the practical learn-by-doing programs [3], the career-design programs [4], the start-up programs for freshmen [5], and the leadership programs in "Smart Dormitory" [6]. We expected that the students would obtain various practical engineering abilities, skills and self-consciousness through these practical programs. So, we have been dealing with the real-existing problems residing in various practical projects in engineering and technologies. The history of our educational reform activities which have been conducted in Faculty of Engineering in Niigata University is given in Fig. 1.

It is very important to build the cooperative activities between the industries and universities when we discuss about the engineering educational reforms [7]. When we deal with the practical engineering education, we thought it would be necessary to get some supports by the wellexperienced engineers and scientists outside the university in addition to the university professors who have lessexperienced than them with respect to the practical businesses and industrial issues. Then, we organized a
TABLE I. THE NUMBER OF "THE NETWORK OF 100 WISES" INTRODUCED BY THE DEPARTMENTS OF FACULTY OF ENGINEERING

\begin{tabular}{|l|c|}
\hline Departments & Number \\
\hline Mechanical and Production Engineering & 16 \\
\hline Electrical and Electronic Engineering & 15 \\
\hline Information Technology & 5 \\
\hline Bio-cybernetic Engineering & 9 \\
\hline Chemistry and ChemicalEngineering & 13 \\
\hline Civiland Architecture Engineering & 5 \\
\hline Material Science Engineering & 7 \\
\hline Others (Alumni/personal relationship etc.) & 17 \\
\hline Total(established in 2008) & 87 \\
\hline
\end{tabular}

novel educational human network what we call "The network of 100 wises", and have invited the engineers and scientists to the network among the partners of collaborative research activities in Faculty of Engineering in Niigata University. In the paper, the authors present the characteristic activities, and discuss the roles and effects of the network.

\section{ENGINEERING SUPPORTERS NETWORK}

\section{A. Building the human network}

"The network of 100 wises" is a sort of supporting system for engineering education for both the students and faculties of Niigata University. Since the specific techniques always reside in the specific engineers, the experienced engineers have various know-how and up-todate knowledge on engineering and technologies in various industrial fields. At the start point of the project of "The supporting program for contemporary educational needs" by the Japanese government in 2006, we invited the engineers and scientists outside the university to take part in our educational activities from the practical and industrial points of view. We have constructed a human network system of technical information, instead of piling up the know-how on the bookshelves.

The network members are broadly experienced in their own practical areas of engineering, and have strong

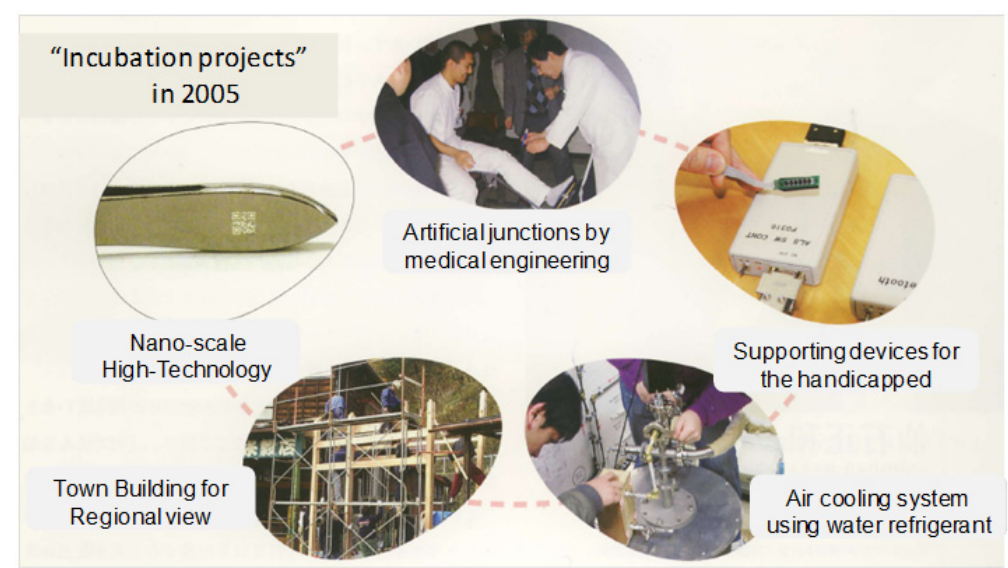

Figure 3. Practical collaborative education programs which started in 2005 and have been guided by the network of 100 wises. 


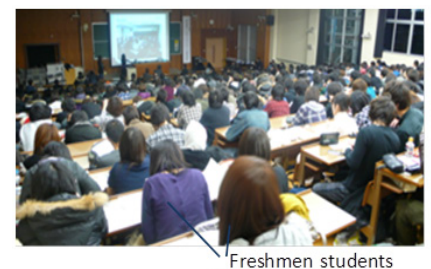

(a)

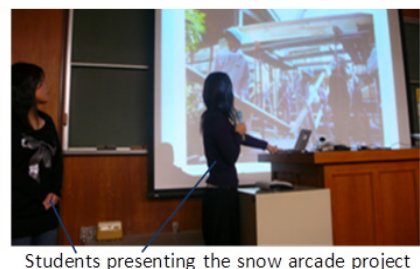

(b)
Figure. 4. Final presentations in the practical learn-by-doing program held in 2009

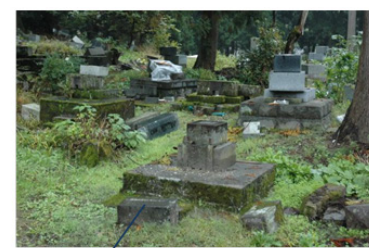

Graveyard shaken in the earthquake

(a)

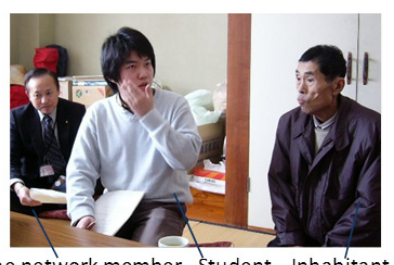

(b)

Figure 5. Views of career design program "Market Internship" as the investigation on the earthquake-stricken area in 2008, the graveyard (a) and the interview to the inhabitants (b).

\section{ACTIVITIES OF THE NETWORK}

motivations to guide university students properly. Eightyseven members have enrolled in the network by 2008 , as
shown in Table 1. After the reconstruction in 2010, fiftyfour engineers and scientists are registered in the network till now in various educational projects as follows.

\section{B. Characteristics of the human network}

The members of the network were nominated from all the departments of Faculty of Engineering covering all the category of engineering. Then, they were carefully chosen mainly by the professors who had been collaborated with each other for years. Since these collaboration projects have been originally based on the academic research activities, the network members have strong relationships and reliance to the university professors with each other. We regard this as the most precious characteristic among other features of the network.

Fig. 2 schematically shows the roles of the human network and the chief members who represents the whole network. The network members have various roles to guide the students, giving them proper technical or engineering information. At the same time, they support the faculties of Niigata University, and cooperate with them as for their activities on the engineering education.

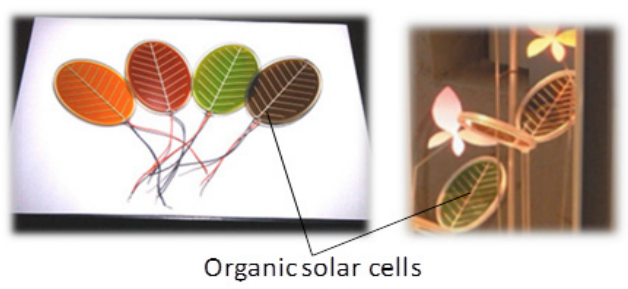

Oillamp

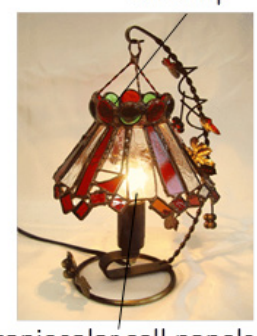

Organic solar cell panels

(b) (a)

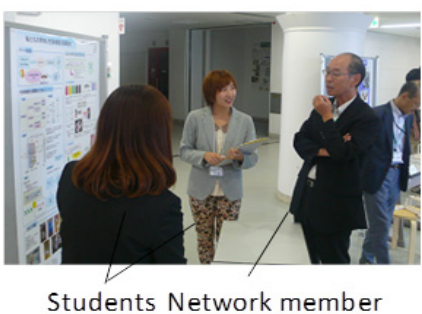

(c)
Figure 6. Investigation on the market and research trends on the organic solar cells (a), an example of the new products proposed by the students (b), and a view of the presentation about the research result in 2014
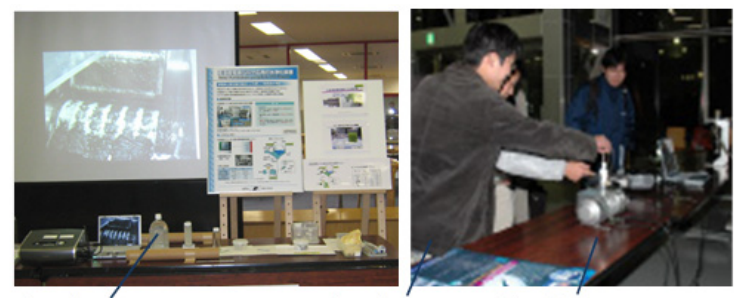

Products

(a)

Students Products

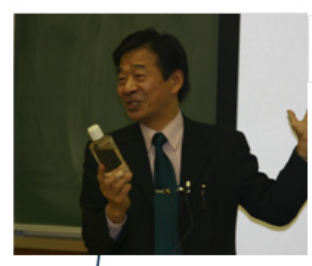

Lecturer of the network

(c)

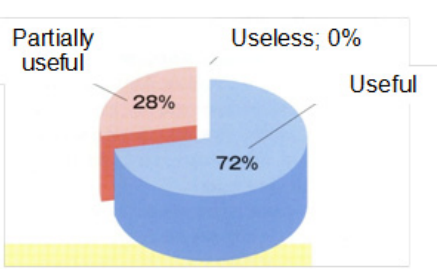

(d)

Figure 7. The exhibition of the company products "Enterprise Week" (a) (b), and the lectures on their practical R\&D stories (c). The products are exhibited for a week. The reputation from the students who took the program of the program is shown in (d). 


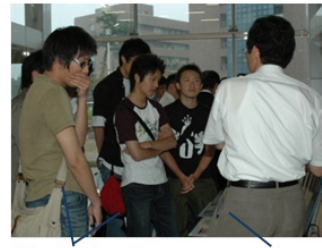

Students Com

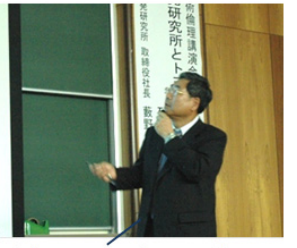

(b)
Figure 8. Views of the presentation (a) and lecture (b) on the engineering ethics by the network member of an automobile-parts

out by these students belonging to the department of architecture in cooperation with the constructors in private companies, the city officials, and the inhabitants in this project, as well as the faculties as the supervisors of the project. After this presentation meeting, eighteen students which corresponded to all the presenters filled in the questionnaire. It showed that the programs were useful, and, in addition, no students answered the program was useless.

In 2006, we started a novel career education program which is characterized by a unique internship program called "Market Internship". In the Market Internship, the students have experienced the engineering technology from the user's view. We aimed that the students become to enable by themselves to gain the consciousness of the worth residing in engineering and technologies. The peculiar feature of the program lies in the investigation activity on the actual spots where the engineering techniques are utilized. The students intend to find the performances of the engineering and technology. In the programs, the network has been assisting the students.

As shown in Fig. 5, a students' team visited the earthquake-stricken area in Niigata prefecture in 2007, and conducted the interviews with guide of the network members to investigate the engineering products which were useful when the disaster happened. Other students investigated the solar cell in the industrial market and proposed their own utility products of their own, as shown in Fig. 6. The students' team made a presentation of the research results in the meeting held in 2014 in attendance with the network members. The program has been continued till now even after the end of financial support by the Japanese government. 27 teams composed by 105 students have taken the subject for a decade so far.

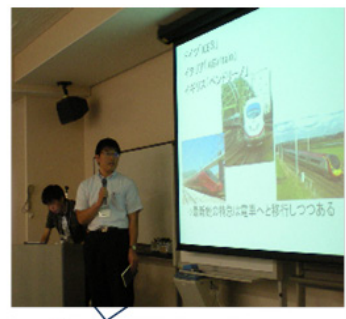

Students

(a)

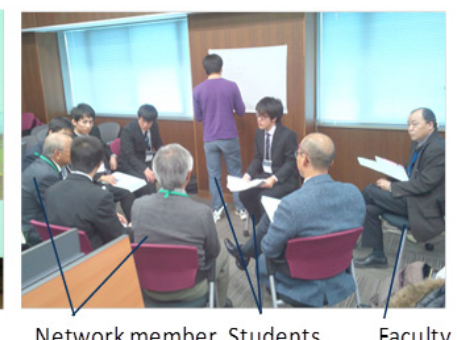

(b)

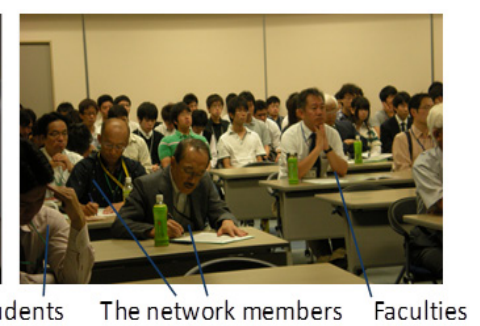

(b)
Figure 10. The presentation given by students on their research activity (a) in the presentation meeting in 2015 and a view of the workshop held in the meeting (b), discussing about the practice in Smart Dormitory.

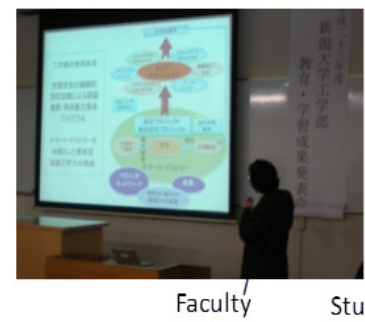

(a)

\section{B. Lectures and exhibitions}

A characteristic education program called "Enterprise Week" was made up of a lecture presented by the company engineers and an exhibition of the industrial products and techniques. As shown in Fig. 7, the practical and ongoing R\&D stories are lectured by the company engineers. Although the topics may occasionally related to so-called the success stories, all the talks have been the practical and real stories based on the speakers' own experiences. At the same time, the commercial products which are practically dealt in various markets were exhibited for the students as the results of outstanding R\&D activities. This program was developed in 2004 as a part of the interdisciplinary programs, and lasted to 2007. This event was totally held for 9 times. It was found that these lectures based on the practical and real instances were popular for the students when we know the fact that all of the participants replied that the programs were useful for them according to the questionnaire result, as shown in Fig. 7(d).

"Engineering Ethics Lectures" deal with the social and environmental problems which occur with the changes of the paradigm shift and the enhancement of the social compliancy. As shown in Fig. 8, the lectures are presented by the network members to let the students learn the ethics on the technologies and enterprises. The lecturer working for an automobile-parts company announced that the technologies were always based on the ethical attitudes and ethical knowledge. The topics on the ethical issues became more and more important nowadays, and the engineering ethics has been assigned to the compulsory subject several years ago. The network members have been hired as the part-time lecturers who possess the reliable opinions through a lot of actual experiences on the engineering ethical issues.

Figure 11. Meeting of the network of 100 wises held prior to the presentation meeting for students, the report on the circumstances of the engineering education by the faculty in 2011 (a), and the discussion of the attending network members in 2012 (b). 
As shown in Fig. 9, the lectures presented by the network members have been planned and performed as a part of the start-up programs called as "Lectures for freshmen" and "Leadership lectures for seniors" [6]. It is effective for the students to motivate their consciousness to their career designing. These lectures have been still continued in every department even after the end of the financial support from the government in 2011.

\section{Presentation meetings on education and study results}

As shown in Fig. 10, the presentation meetings have been held twice a year in attendance of the network members, faculties, and students. In every meeting, the students report their investigation results and experiences of the practical engineering education programs they took. Fig. 10(a) shows a research projects voluntarily conducted by the undergraduate students before starting their graduation researches in "Smart Dormitory" in 2015. The experiences of these talks are quite beneficial for them to obtain the presentation techniques and communication skills.

The discussion meetings named "Career Design Workshop" were conducted at the same time among the students, the network members, and faculties, as shown in Fig. 10 (b). In the meetings, the network members pointed out, for example, the shallow analyses of the student participants with respect to their research activities, while they gave them high evaluations on their reports on summarizing the practices.

The university students know little how to behave in the practical societies where they would join in near future, while the network members do not know much about the present condition and consciousness of university students with respect to their scholastic abilities, adaptability to the company societies and so on. Therefore, it is definitely important to talk and discuss together at the same table and time to know the various gaps in their different circumstances and consciousness on the topics of engineering and technology.

The network members have another important role of giving the university faculties the opinions and evaluations for the educational reform activities. As shown in Fig. 11, the meetings of the network of 100 wises have been held at every presentation meeting at the same time beforehand the student' presentations. The topics on the educational conditions such as the government trends, the conditions of applications, and the progress of the budgets were reported by the faculties and discussed among the faculties and the engineers there. It is quite beneficial for both the network members and faculties that they may directly get information of each other between universities and the industrial societies.

As shown in Figs. 12 and 13, after the questionnaire results from the network member at the presentation meeting in 2014, the major comments against the students' activities are gathered to their shallow analysis. On the other hand, they regarded the students' activities as beneficial for them. The presentation skills of the students to summarize the topics were highly estimated, too. As shown in Fig. 13, the most important ability for the students was selected as the communication skills to the job circumstances, whereas the scholastic ability was positioned in the low-level requirement. This result apparently reflects the necessity of education reform which industrial societies demand to universities. The faculty or the education system in universities tends to position the students who have well-understanding ability and high scholastic knowledge at the high grade. However, all the graduates are not assigned or hired as the scientific researchers in the society. The students are rather required to be practically well-trained and to possess the practical engineering abilities when they are recruited. We must realize and understand the difference of the consciousness between the university which educates the students and the companies which hire the students in the practical society.

\section{CONCLUSION}

We have operated five kinds of practical engineering education programs of the interdisciplinary, the career designing, the practical learn-by-doing, and the start-up for freshmen, and leadership programs. All of these programs have been supported by the engineers and scientists of companies and societies outside the university. Since the specific techniques always reside in the specific engineers, the experienced engineers have an abundance of know-how and up-to-date knowledge on engineering and technologies in various industrial areas. The guidance, lectures and assistances by the network have made a lot of beneficial contributions to the education of university students. According to the questionnaire results, as the necessity of cooperation between universities and industries tends to increase, the role of "The network of 100 wises" will become important more and more in near future.

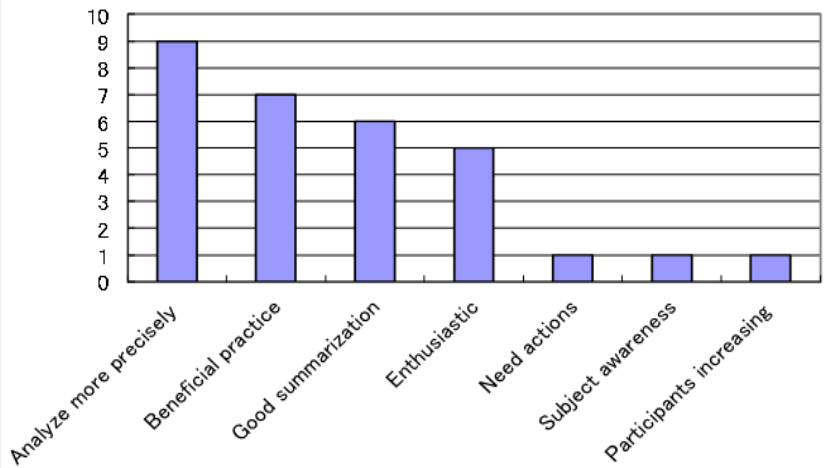

Figure 12. Opinions to the students' activities by the network members. The data were obtained from the questionnaire after the presentation meeting in 2014.

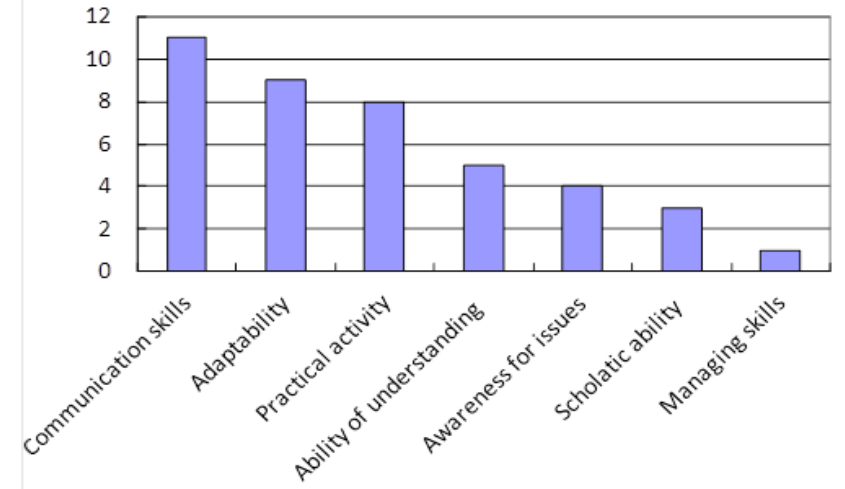

Figure 13. The engineering abilities required to the university students. 


\section{ACKNOWLEDGMENT}

The works were originally designed in cooperation with Prof. Harada in Niigata University, and have been supervised by our deans Prof. Ohkawa, Prof. Tsubokawa, and Prof. Kaneko. The projects have been supported by Ms. Terasawa, Ms. Ishii, Mr. Haneda, and Mr. Hatori in Niigata University. The authors cordially give them great thanks for their contributions. The projects have been supported by the grants-in-aid from MEXT of the Japanese government.

\section{REFERENCES}

[1] R. Miller with J. Euchner, "The Future of Engineering Education", Research-Technology Management, pp. 15-19, Jan.-Feb. 2014.

[2] Y. Tanabe, T. Narumi, T. Oka, S. Harada, K. Abe, T. Sato, T. Maruyama, H. Ohkawa, "Current Status and Future Development of Kougaku-Ryoku Education", 12th IACEE World Conference on Continuing Engineering Education (12th WCCEE), Singapore, 1719 October, No. 146, pp. 250-257, 2010.

[3] S. Nishimura, N. Ishii, M. Sengoku, T. Maruyama, T. Sato, Y. Tanabe, A. Ohkawa, A. Sugawara, I. Nitta, and T. Oka, "Incubation of technical collaborations for learn-by-doing educational program through engineering developments", 10th IACEE World Conference on Continuing Engineering Education (10th WCCEE), Vienna, Austria, 19-21 April, 384, 2006.

[4] T. Oka, Y. Tanabe, S. Nishimura, H. Imaizumi, S. Harada, N. Ishii, K. Abe, Y. Iwabe, T. Haneda, H. Soma, K. Terasawa, T. Maruyama, H. Ohkawa, M. Sengoku, "Project-based Engineering Career Education Programs by the Collaborations with Private
Companies", 11th IACEE World Conference on Continuing Engineering Education (11th WCCEE), Atlanta, 20 May, No. 178, 2008.

[5] K. Yamagiwa, Y. Tanabe, S. Harada, T. Shimizu, T. Oka, "Startup Engineering Education Programs for First Year Students", 12th IACEE World Conference on Continuing Engineering Education (12th WCCEE), Singapore, 17-19 October, No. 57, pp. 345-352, 2010. http://dx.doi.org/10.3850/978-981-08-7156-7_p057

[6] T. Oka, T. Yamauchi, K. Abe, T. Narumi, Y. Tanabe, "Educational Programs Based on Specialized Scientific Research Projects for Freshmen", 4th Asian Conference on Engineering Education (ACEE2014), 11 October, Kumamoto, GS-2-4-2, pp.183-186, 2014.

[7] W. Kang, "A Strategy for Supporting the Learning Community in Cooperation with Industry", J. Engineering Education Research, vol. 13, No. 2, Special Edition, ISSN 1738-6454, pp. 12-15, 2010.

[8] This article is an extended and modified version of a paper presented at the International Conference on Interactive Collaborative Learning (ICL2015), held 20-24 December 2015, in Florence, Italy.

\section{AUTHORS}

T. Oka, K. Abe, T. Yamauchi, T. Narumi, N. Ishii, S. Nishimura, T. Sato, and Y. Tanabe are with Niigata University, Niigata, Japan.

M. Sengoku is with the Graduate Institute for Entrepreneurial Studies, Niigata, Japan.

Submitted 12 December 2015. Pubished as resubmitted by the authors 28 January 2016. 